\title{
MARKETING PERCEPTION OF SELECTED CUSTOMERS' SEGMENT IN THE FINANCIAL SERVICES MARKET
}

\author{
[Marketingové vnímání vymezeného segmentu zákazníků na trhu finančních \\ služeb]
}

\author{
Kateřina Matušínská ${ }^{1}$ \\ ${ }^{1}$ Slezská univerzita, Obchodně podnikatelská fakulta, Univerzitní nám. 1934/3,73340 Karviná \\ Email: matusinska@opf.slu.cz.
}

\begin{abstract}
The paper deals with behaviour of the segment 50+ in the financial market in the Czech Republic (Moravian-Silesian Region). This segment could be said as the strong market power and it can be a crucial business potential for financial business units. The main defined objective of this paper is description of the customers' behaviour of the segment 50-60 years in the financial market in the Czech Republic (Moravian-Silesian Region) in the area of product, price, distribution and marketing communication policy. This paper is based on secondary data and data from primary marketing research. Paper determinates the basic problem areas as well as definition of financial services marketing, population aging in the Czech Republic, defining the primary research problem, hypotheses and primary research methodology. Finally the hypotheses are assessed and suitable marketing approach to selected segment at age of 50-60 years is proposed according to marketing research findings.
\end{abstract}

Keywords: financial services marketing, population aging in the Czech Republic, secondary and primary marketing research, segment $50+$.

JEL classification: G20, M31

Doručeno redakci: 13.8.2014; Recenzováno: 3.9.2014; 30.9.2014; 12.10.2014; Schváleno k publikování: 27.5.2015

\section{Úvod}

Charakter finančního trhu v České republice před rokem 1989 dlouho způsoboval, že finanční instituce pomalu přijímaly marketingovou filozofii a nevěnovaly př́liš pozornosti svým zákazníkům. Po zásadních politických změnách ke konci 90. let dochází ke zvyšování nároků zákazníků, deregulaci trhu, vývoji nových technologií a k zintenzivnění konkurence. Finanční instituce přehodnotily svůj př́stup k zákazníkům a k trhu, začaly vznikat nové produkty, prezentované novým způsobem, a poskytované prostřednictvím nových distribučních kanálů. Finanční instituce se orientují na marketingový př́stup tzv. kustomizaci a v rámci strategie zacílení intenzivněji aplikují koncentrovaný marketingový přístup, popřípadě ryzí one-to-one marketing (privátní bankovnictví).

Dř́ve, finanční instituce používaly pro analýzu zákazníků (a to nejen v České republice) tradičně pouze finanční analýzy, a to zejména $\mathrm{v}$ oblasti poskytování úvěrů, pojištění a podobně. Výsledky této analýzy mají jen nominální význam. Pokud chceme realizovat solidní segmentaci trhu, je potřeba se seznámit s chováním zákazníka. V opačném př́padě nejsme schopni rozpoznat důležité charakteristiky zákazníků dané jejich demografickými a behaviorálními znaky. Tato zjištění jsou zapotřebí pro optimální využití marketingového komunikačního př́stupu a nastavení kvalitního marketingového plánu. Současným trendem je, že finanční instituce využívají ve větší míře cílený marketing. Snaží se poskytnout finanční produkty, které vyhovují konkrétnímu tržnímu segmentu. Pak je možné oslovit segment odpovídajícím výrobkovým, cenovým, komunikačním přístupem přes vhodně zvolené distribuční sítě. 
Úspěch finanční instituce na trhu závisí také na jasném vymezení cílové skupiny. To mohou být aktuální nebo potenciální uživatelé produktu nebo značky, jednotlivci nebo skupiny lidí, kteří se rozhodují o koupi. Jejich podrobná charakteristika je nezbytným předpokladem pro další postup, který představuje upřesnění toho, co, jak, kdy a kde se nabízet a komunikovat. Budoucnost marketingové orientace společností je třeba hledat $\mathrm{v}$ segmentech, které lze považovat za marketingový potenciál budoucnosti. Tento článek se zaměřuje na zhodnocení spotřebitelského chování specifického a významného tržního segmentu 50+ na trhu finančních služeb v České republice.

Cílem tohoto článku je popsat spotřebitelské chování vymezené cílové skupiny zákazníků na trhu finančních služeb v České republice (Moravskoslezském kraji), a to ve věkové kategorii 50 - 60 let. Článek se zaměřuje na definování marketingu finančních služeb, problematiku stárnutí populace, dále definuje problém, hypotézy a metodiku primárního marketingového výzkumu. V závěrečné části jsou stanovené výzkumné hypotézy na základě výstupů zrealizovaného primárního marketingového šetření potvrzeny či vyvráceny. Zároveň jsou navrženy marketingové postupy pro danou vymezenou cílovou skupinu zákazníků $\mathrm{v}$ rámci produktu, ceny, distribuce a marketingové komunikace.

\section{Specifika marketingu finančních služeb}

Marketing se zabývá vztahem mezi kupujícím a prodávajícím a vzájemně prospěšnými transakcemi mezi těmito účastníky trhu. Marketing je založen na myšlence, že zákazník je středem pozornosti pro všechny osoby pracující v organizaci. Moderní marketingový koncept může být vyjádřen jako: dosahování podnikových cílů prostřednictvím splnění očekávaných potřeb zákazníků lepším způsobem než konkurence. (Jobber, 2010)

Služba je nehmotný produkt zahrnující skutek, výkon nebo úsilí, které nelze skladovat nebo fyzicky uchopit. (Dibb a Simkin, 2004, s. 234) Služby jsou zvláštní druh produktu. Mohou vyžadovat speciální znalosti a speciální marketingové úsilí. (Jobber, 2010, s. 822) Finanční služby jsou zaměřeny na jednotlivce (B2C trh - spotřebitelský trh) nebo organizace (B2B trh - trh organizací) a jejich finance. Pojem finanční služba je často používán široce pro celou škálu finančních služeb jako je například pojištění (životní i neživotní), obchodování na burze, správu aktiv, platební karty, běžné účty, stavební spoření, financování obchodu, rizikový kapitál a další. (Waite a Ennew, 2007)

Finanční služby mají své vlastní charakteristické vlastnosti, které jsou založeny na odlišnosti od fyzického zboží. Dle Levense (2012) existují čtyři způsoby, kterými se služby liší od fyzického zboží - nehmatatelnost, neoddělitelnost, pomíjivost a variabilita. Nehmatatelnost - zákazník si nemůže být před koupi jistý, jaké benefity od služby obdrží. Tato charakteristika je typická pro všechny typy služeb. Nehmatatelnost finančních služeb má některé společné rysy, jako jsou nízké náklady na vstupu, rychlost uvedení na trh a nedostatek exkluzivity. (Ehrlich a Fanelli, 2012) Neoddělitelnost - ve většině případů poskytnutí služby je vázáno na př́mou součinnost poskytovatele a př́jemce služby. Zákazníci finančních služeb jsou aktivně zapojování do vytváření nabídky finanční služby. Zákazníci mohou být identifikováni jako skuteční nebo potenciální kupující finanční služby s řadou nákupních rolí jako je iniciátor, ovlivňovatel, rozhodovatel, kupující a uživatel. (Gamble et al., 2006) Pomíjivost služby nelze skladovat pro pozdější použití. To nemusí být nutně komplikace, pokud služby vykazují konstantní úroveň poptávky, ale na trzích s výkyvy poptávky tato charakteristika může zpo̊sobovat určité problémy. Variabilita - kvalita poskytovaných služeb závisí na faktorech, které jsou obtížně kontrolovatelné a souvisí s lidským faktorem. Drummond a Ensor (2005) přidávají další charakteristiku, jako je nemožnost vlastnictví, protože služba 
nemůže být vlastněna jako taková, zákazníci si mohou pouze koupit př́stup ke konkrétní službě pro určité časové období. Je důležité zdůraznit, že finanční služby mají další unikátní vlastnosti, které představuje dlouhodobost, odložená spotřeba a přenesená zodpovědnost. (Waite a Ennew, 2007)

Marketingové aktivity $\mathrm{v}$ oblasti finančních služeb jsou obvykle strukturovány v rámci marketingového mixu. McCarthy uvádí marketingové nástroje v konceptu „4P“ - produkt, cena, distribuce a marketingová komunikace. (Kotler a Keller, 2012) Nicméně, charakteristické rysy finančních služeb vyžadují doplnění dalších třech prvků - lidé, materiální prostředí a procesy. Potřeba rozšíření marketingového mixu je vzhledem k vysoké míre př́mého kontaktu mezi organizací a zákazníkem a simultánnosti produkce a spotřeby. (Pirrie a Mudie, 2006)

Vztahy vytvořené mezi kupujícími a prodávajícími musí být postaveny na vzájemné důvěře, nebot' mají velký dopad na budoucí nákupní chování zákazníků a na ústně šířené reference. Ze své podstaty nelze finanční služby považovat za jednorázovou transakci, ale jsou založeny na dlouhodobém a vzájemně důvěryhodném vztahu mezi zákazníkem a poskytovatelem. (Ennew et al., 1995) Aktivní vztah k zákazníkům pomocí CRM nachází podstatné uplatnění především na trzích finančních služeb. Customer Relationship Management (CRM) představuje aktivní tvorbu a udržování dlouhodobě prospěšných vztahů se zákazníky. Komunikace se zákazníky je přitom zajištěna vhodnými technologiemi, které představují pro akcionáře i pro zaměstnance firmy samostatné procesy a technologie. (Wessling, 2003, s. 16)

\section{Demografické stárnutí spotřebitelů v České republice}

Demografické stárnutí je základní charakteristikou současného vývoje všech populací evropského typu. Dlouhodobý pokles úmrtnosti vedoucí k prodlužování průměrné délky života a dlouhodobý pokles plodnosti vede ke zvyšování počtu starších osob (obrázek č. 1). Populační stárnutí mělo doposud poměrně klidný průběh a jednalo se především o tzv. stárnutí zespoda věkové pyramidy. To znamená, že se snižoval podíl dětí v populaci, zatímco osob ve vyšším věku přibývalo pouze velmi pozvolně. $V$ dalším období začne počet osob starších 65 let intenzivně přibývat, jak se tohoto věku začnou dožívat početně silnější generace narozených po roce 1940. Na intenzitě nabere tento proces v období 2011 - 2017, a to $\mathrm{v}$ důsledku přechodu silných poválečných ročníků přes tuto věkovou hranici. Relativní zastoupení těchto osob v populaci poroste ale také díky poklesu počtu narozených. Výrazné změny ve věkovém složení se pak promítnou do hodnot dalších ukazatelů - průměrný věk by se v roce 2050 mohl pohybovat mezi 48 a 50 lety, což by bylo zhruba o deset let více než je tomu dnes. Ženy mají průměrný věk zhruba o tř̌i roky vyšší než muži a tak např́íklad podle střední varianty by měl průměrný věk žen v roce 2050 dosáhnout 50,2 let a průměrný věk mužů 47,3 roku (v roce 2002 to bylo 40,8, resp. 37,7 roku). Značnou měrou vzroste i index stáří (65+), který vyjadřuje počet osob ve věku 65 a více let připadající na 100 osob ve věku 0-14 let. Hodnoty $100 \%$ dosáhne, když jsou podíly obyvatel do 14 a nad 65 let shodné a populace $\mathrm{v}$ před-produktivním věku je stejně početná jako počty osob v post-produktivním věku. Podle střední varianty projekce by počet obyvatel starších 65 let převyšoval počet dětí do 15 let $\mathrm{v}$ horizontu projekce 2,5krát, podle nízké dokonce více než 3,5krát. Za celou populaci dosáhla hodnota indexu stáří na konci roku 200597 \%, rozdíly mezi muži a ženami jsou zásadní. Zatímco u žen převažuje počet osob třetí generace nad nejmladšími již od roku 1998, u mužů hodnota indexu stáŕí, vzhledem k nižšímu průměrnému věku a nižší naději dožití, nedosáhla ještě 80 \%. V evropském kontextu lze hodnotu indexu stáří v ČR považovat 
za průměrnou, srovnatelných hodnot jako Česká republika dosahují např. Belgie (99\%), Rakousko (99 \%), Švédsko (98 \%) nebo Švýcarsko (97\%). ${ }^{1}$

Obrázek 1: Stromy života - projekce obyvatelstva ČR v letech 1980 a 2050
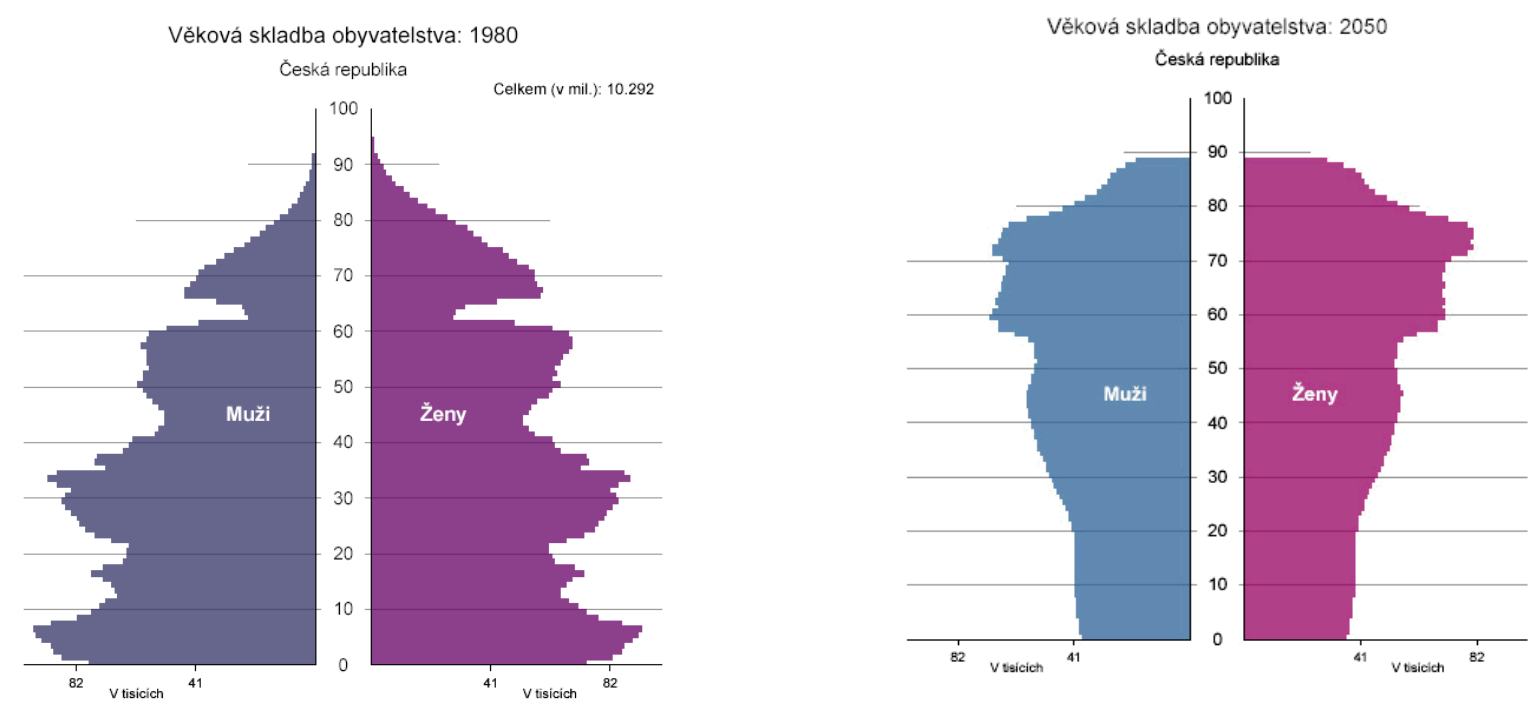

Zdroj: Webový portál ČSÚ. Projekce obyvatelstva [online]. [vid. 8. srpna 2014]. Dostupné z: http://www.czso.cz/animgraf/projekce_1950_2101/index.htm

To znamená, že obyvatelstvo České republiky na přelomu 20. a 21. století je nejstarší v celé své dosavadní historii. Toto je možné konstatovat i o obyvatelstvu ostatních evropských zemí, v ČR je však perspektiva dalšího populačního stárnutí zřetelnější než ve většině z nich. Silný kontingent narozených v polovině 70 . let zřejmě zůstane v prvních třech dekádách 21 . století nejpočetnější věkovou skupinou obyvatelstva. Kolem roku 2015 budou nejpočetnější skupinou obyvatelstva čtyřicetiletí, kolem roku 2030 pětapadesátiletí a pravděpodobně ještě v roce 2040 budou pětašedesátileté osoby představovat zvlášt' výraznou složku obyvatelstva. Další velmi početnou generací budou ovšem i narození kolem roku $1950{ }^{2}$

Význam této skupiny do budoucna bude navíc vzrůstat a to především proto, že celá populace České republiky stárne, a proto se bude tato skupina početně rozrůstat. Dnešní starší generace je z jejího pohledu a spotřebním chováním několikanásobně mladší, než tomu bylo před 20 lety. Generace lidí nad 50 let je časově i finančně nezávislá a je považována za nejbohatší generaci světa. V prostředí ekonomiky České republiky to zatím zcela neplatí, posun je však nicméně záležitosti následující generace. $\mathrm{V}$ budoucnu budou mladí lidé potřebovat stále méně a starší lidé stále více produktů a služeb. Spotřební síla budoucnosti patří novému věku, nebot' generace nad 50 let už po léta neustále vytlačuje 14leté až 49leté osoby z jejich spotřebního prvenství. Obory jako turismus, bydlení, finance, mobilita, vzdělání, sport a fitness, stravování a relaxační centra jsou těmi obory, které mohou profitovat z demografických změn. (Reidl, 2012) Predikovaný demografický vývoj dospívá k jednoznačnému závěru podniky, které si chtějí udržet své postavení na trhu a být ziskovými i v budoucnosti, musí oslovit a získat si i starší zákazníky.

\footnotetext{
${ }^{1}$ Webový portál ČSÚ. Projekce obyvatelstva [online]. [vid. 8. srpna 2014]. Dostupné z: http://www.czso.cz/csu/ 2004edicniplan.nsf/p/4025-04

${ }^{2}$ Webový portál Marketingové noviny. Cílová skupina seniorů a její zvyklosti [online]. [vid. 8. srpna 2014]. Dostupné z: http://www.marketingovenoviny.cz/marketing_1941/
} 


\section{Přípravná fáze marketingového výzkumu}

V rámci orientační analýzy byly použity sekundární informace, která doplňují informace získané primárním marketingovým šetřením. Základní sekundární informace byly získány především z databáze Českého statistického úřadu, domácí a zahraniční odborné literatury a dostupných studií. Vzhledem k druhu požadovaných informací a zkoumané problematice, byla zvolena metoda osobního dotazování. Výběrový vzorek tvořilo 306 respondentů z Moravskoslezského kraje. Jako technika výběru vzorku respondentů byla použita nereprezentativní technika vhodného úsudku, kdy byli osloveni respondenti na základě předpokladu, že lze získat správné údaje. (Kozel et al., 2006) Výběrový soubor respondentů byl sestaven tak, aby byl relevantní vzhledem k základnímu souboru respondentů, který představuje všechny osoby ve věku 50-60 let s trvalým bydlištěm v Moravskoslezském kraji (197 720 osob k 31. 12. 2008). Primární výběrové šetření bylo realizováno v měsíci březen květen 2013.

Hlavní výzkumný problém představoval nepřiměřené respektování základního demografického vývoje (stárnutí populace) ze strany poskytovatelů finančních služeb v České republice a související zanedbávání významného tržního potenciálu generace $50+$. Cílem tohoto výzkumu bylo popsat chování českých zákazníků cílové skupiny ve věku 50 až 60 let na trhu finančních služeb. Následující čtyři pracovní hypotézy byly definovány pro účely marketingového výzkumu:

- H1: Úvěrové produkty má sjednáno méně než $40 \%$ respondentů.

- H2: Více než 30 \% respondentů upřednostňuje elektronickou formu komunikaci s finanční instituci prostřednictvím Internetu.

- H3: Největší vliv při rozhodování o výběru finanční instituce mají referenční skupiny.

- H4: Segment ve věku 50-60 let je neheterogenní skupina zákazníků na trhu finančních služeb v rámci různých př́imových kategorií. Na základě této hlavní hypotézy byly stanoveny dílčí hypotézy:

- H4.1: Poptávka po finančních službách (typ finančního produktu) je závislá na velikosti př́jmu segmentu 50-60 let.

- H4.2: Senzitivita na cenové podmínky finančních produkti̊ je závislá na velikosti př́ijmu segmentu 50-60 let.

- H4.3: Preference distribučního kanálu finančních služeb je závislá na velikosti př́ijmu segmentu 50-60 let.

- H4.4: Efektivita vybraných motivačních faktorů ke koupi je závislá na velikosti př́jmu segmentu 50-60 let.

Tabulkový procesor MS EXCEL byl použit pro vyhodnocení získaných primárních informací. Stanovené pracovní hypotézy byly vyhodnoceny pomocí popisných statistik (absolutní a relativní četnosti odpovědí). Chí-kvadrát test byl aplikován $\mathrm{k}$ analýze závislosti dvou proměnných v rámci vybraných aspektů spotřebitelského chování respondenti̊ ve věku 50-60 let versus jejich př́jmy. V rámci postupu testování statistických hypotéz v tomto článku byly formulovány nulové a alternativní hypotézy, vypočteno testovací kritérium, nalezen obor přijetí a kritický obor a na závěr rozhodnuto, zda vypočtená hodnota testového kritéria padne do kritického oboru, to znamená, že nulová hypotéza bude zamítnuta a alternativní hypotéza H1 bude přijata na hladině významnosti $\alpha(0,05)$.

\section{Výsledky a diskuze}

V rámci primárního šetření bylo osloveno 45 \% mužů a 55 \% žen, kdy dominantní je jejich středoškolské vzdělání a rodinný stav ženatý/vdaná. Největší př́ijmová skupina je v kategorii 
do 20000 Kč (48 \%), dále v kategorii 20001 až 50000 korun, do které se řadí $37 \%$ respondentů. Pouze 4 \% uvádí př́ijem vyšší než 50000 Kč. Mezi identifikačními údaji, jako je vzdělání a prř́jem, lze nacházet určitou vzájemnou korelaci. Lidé s vyšším vzděláním převážně dosahují i vyšších př́íjmů, což platí i u tohoto provedeného primárního šetření.

Zákaznické chování segmentu 50-60 let na finančním trhu lze hodnotit jako racionální a obezřetné. Před sjednáním samotného finančního produktu většinou vyhledávají informace prostřednictvím kontaktního personálu finanční instituce a dále využívají ostatní zdroje informací (Internet, reference, tisk apod.). 27 \% respondentů uvádí, že na jejich rozhodnutí nemá v žádném př́padě vliv prodejce, ale aktivně se sami o informace týkající se finančního produktu zajímají. Čeští zákazníci jsou na finančním trhu relativně stabilní a nevyznačují se značnou fluktuací. Více než 50 \% respondentů uvádí, že za posledních 10 let nezměnili svou banku, pojišt'ovnu nebo stavební spořitelnu. Finanční gramotnost lze označit jako průměrnou. Při dotazování respondenti označili 5 z 10 finančních pojmů, které neznají. Jedná se např́íklad o pojmy jako CashBack, ATM (bankomat), Revolvingový úvěr apod.

Mezi nejfrekventovaněji využívaný finanční produkt, dle očekávání, patří běžný účet (97 \%). Zajímavé je zjištění, že pouze polovina uživatelů běžného účtu použivá v rámci platebního styku debetní platební kartu, která se $\mathrm{k}$ účtu váže. 56 \% aktivních uživatelů debetní platební karty ji používá k placení a 50 \% k výběru z bankomatu. Je zde jednoznačně vidět, že dochází ke změně trendu a přibližování se evropskému standardu, nebot' ještě v nedávné minulosti platební karta plnila především funkci výběru finančních prostředků z bankomatu. Dále také převažují finanční produkty jako penzijní připojištění (74 \%), životní pojištění $(51 \%)$, stavební spoření $(47 \%)$ a neživotní pojištění (46 \%). Krátkodobé a dlouhodobé úvěrové produkty mají spíše minoritní zastoupení. Jedná se např́iklad o hypoteční úvěr (15\%), krátkodobý spotřebitelský úvěr (10\%), leasingový úvěr $(5 \%) .36 \%$ respondentů využívá kreditní platební kartu, která se řadí do kategorie úvěrových produktů. Řada uživatelů tohoto typu platební karty si ji však pořizuje spíše kvůli výhodám doplňkových služeb, které jsou s ní spojené. Zvýšený zájem o tento platební instrument je také podmíněn masivní intenzivní marketingovou komunikační kampaní finančních institucí.

Celkově lze konstatovat, že segment 50-60 let spíše inklinuje ke spořicím produktiom než k úvěrovým a sjednává si také produkty eliminující ztráty (životní a neživotní pojištění, úrazové pojištění). Tato zjištěná skutečnost je dána především vyšší současnou veřejnou osvětou v oblasti finanční gramotnosti v ČR, dále změnou př́stupu zákazníků k zadluženosti, kdy čím dál tím více převládá opatrnost, racionálnost a zodpovědnost. Tvorba finančních rezerv a minimalizace finančních závazků slouží pro zajištění si určitého životního standardu i ve stář́. Úvěr má většina respondentů sjednaný pouze na úhradu nezbytných potřeb (36 \%), zároveň před sjednáním úvěru věnují velkou pozornost úvěrovým podmínkám, důsledně získávají informace před podepsáním úvěrové smlouvy. $30 \%$ respondentů dokonce uvádí, že žádný úvěr nemá sjednaný, čerpá pouze vlastní našetřené finanční prostředky. Hypotéza H1 je přijata, nebot' úvěrové produkty má sjednáno 30 \% respondentů.

S cenovou politikou (poplatky, úrokové sazby, sankce apod.) finančních institucí je třetina respondentů spokojena. $55 \%$ uvádí svou nespokojenost, ale není to pro ně zásadní důvod ke změně finanční instituce. Pouze $10 \%$ je ochotno z důvodu své nespokojenosti oslovit novou konkurenční finanční instituci a $4 \%$ se přiklání k radikálním řešením jako je např. soudní spor s bankou. Na základě výsledků šetření lze celkově usuzovat, že česká finanční veřejnost je nespokojená, cenově citlivá, náročná a přesto konzervativní a pohodlná. Cenová elasticita poptávky českého zákazníka po finančních produktech je obecně nižší. Mezi 
základní překážky mobility českých zákazníků se řadí zejména informační asymetrie, laxní př́stup zákazníků, produktové balíčky, sankce za zrušení stávajících produktů a administrativní břemeno. Pro eliminaci administrativní zátěže při změně stávající banky vydává Česká bankovní asociace tzv. Kodex mobility klientů, který musí zúčastněné banky dodržovat a usnadnit tak zákazníkům přechod ke konkurenčnímu subjektu. Finanční instituce mohou eliminovat nespokojenost zákazníků s cenovou nabídkou a zajistit si jejich retenci rozširrením doplňkového produktu (dodatečných služeb k základnímu produktu). Nabízí se zde i velké možnosti pro prodejní strategii Cross-sellingu (křížového prodeje) a Up-sellingu (prodeje navýšení), nebot' $73 \%$ respondentů uvádí, že jsou ochotni při jednání s osobním prodejcem si zřídit další finanční produkt nebo dražší variantu stávajícího finančního produktu.

$\mathrm{V}$ rámci distribuční politiky je zřejmé, že osobní kontakt je stále zcela zásadní (neoddělitelnost) mezi poskytovatelem a př́ijemcem finanční služeb, což je jedna z charakteristik služby. S dynamickým a kontinuálním rozvojem informačních technologií a fenoménem času, čím dál tím více finančních služeb je poskytováno prostřednictvím tzv. technologické distribuce (internetové bankovnictví, telefonické bankovnictví, mobilní bankovnictví, služby bakomatu apod.). Vzhledem $\mathrm{k}$ požadavkům na dobrou znalost informačních technologií, př́stupu $\mathrm{k}$ internetovému připojení, možnosti technologické distribuce spíše oslovují mladší cílovou skupinu zákazníkủ. Přri komunikaci s finanční institucí segment 50 - 60 let preferuje osobní kontakt, bud' na kamenné pobočce (42\%), na jiném domluveném místě (37\%) nebo prostřednictvím telefonu (30\%). Neosobní formy kontaktu, jako je např́íklad Internet, jsou zastoupeny v malé míře $(8 \%)$. Hypotéza $\mathbf{H} 2$ není přijata, nebot' elektronická forma komunikace s finanční institucí prostřednictvím Internetu je preferována pouze $8 \%$ respondenty.

I přesto, že je trendem zrychlovat a zlevňovat proces poskytnutí finanční služby využitím technologické distribuce, osobní setkání v kamenné pobočně stále má a i v budoucnu bude mít nezastupitelnou roli. V 80. letech 20. století nejdůležitějších distribučním kanálem byla pobočka, dále pošta, bankomat a telefon. V současnosti se důležitost kamenných poboček mírně snížila, význam stoupl u bankomatu, telefonu a nově se preferuje Internet. Do budoucnosti lze očekávat, že pozice kamenných poboček bude stále stejná, zvýší se vliv Internetu, bankomatu, mobilních telefonu, budou vznikat nové alternativní kanály "tváři v tvář”. Finanční instituce vnímají potřebu marketingové orientace také v oblasti distribuční politiky. Realizují řadu výzkumu spokojenosti zákazníků s prodejním místem, masivně inovují své pobočky, implementují nové technologie (videohovory, biometrické metody apod.) a zavádějí nové koncepce prodeje (banko-kavárny, banko-prodejny vybraného zboží). $\mathrm{Z}$ marketingového hlediska by poskytovatelé finančních služeb měli pochopit a implementovat merchandising do svých marketingových komunikačních strategií. Ve vztahu $\mathrm{k}$ významu místa prodeje, nelze ignorovat stále významnější roli POP/POS materiálů v komunikaci se zákazníkem přímo na místě prodeje. (Matušínská, Starzyczná a Stoklasa, 2013) V současné době lze také zaznamenat nové trendy v oblasti distribuce finančních služeb v České republice, zavádí se např́iklad koncept minipoboček, bankovních kiosků, pojízdných poboček a další. Snahou je přiblížit bankovní prostředí zákazníkům - lidem.

Při rozhodování o výběru finanční instituce mezi zásadní kritéria respondent řadí cenovou politiku, fyzickou dostupnost prodejních míst a názory referenčních skupin. Individuální př́stup s možností mít vlastního finančního poradce není pro ně prioritní, zároveň se potvrdila nedůvěra a nezájem o služby finančně poradenských firem. I přesto, že využití marketingové komunikace je v silném konkurenčním prostředí nezbytné, prezentace prostřednictvím 
komerčních médií je $v$ nejmenší oblibě. Hypotéza H3 není přijata, nebot' referenční skupiny nelze považovat za zásadní faktor při výběru finanční instituce.

I když z výsledků šetření je zřejmé, že komerční komunikace je jako informační zdroj a motivační stimul pro segment 50-60 let skoro bezvýznamná, nelze ji z marketingově komunikačních aktivit finančních institucí vyloučit. Bylo by vzhledem $\mathrm{k}$ cílové skupině efektivnější spíše využívat nástroje BTL (podlinkové) komunikace. Dle výzkumu se jeví jako vhodné využívat direct marketing, především formou direct mailu (33\% respondentů), dále nástroje v oblasti podpory prodeje jako je vyzkoušení produktu po určitou dobu zdarma (61 \%) a pobídky v rámci Cross-sellingu neboli křížového prodeje (67 \%). Cílová skupina není nakloněna novým marketingově komunikačním trendům, ale nabízí se zde velký komunikační potenciál voblasti WoM (šeptandy, ústního neformálního šíření komerčního sdělení) a virálního marketingu s využitím elektronických médií. Zároveň by mohlo být efektivní vzhledem k cílové skupině využít možnosti Event marketingu (Marketingu událostí).

Pro testování a ověření závislostí mezi úrovní př́ijmu a spotřebitelským chováním segmentu 50-60 let byly vybrány oblasti, jako je užití finančních produktů, senzitivita na cenové podmínky, preference distribučního kanálu a účinnost vybraných faktorů na rozhodování o koupi. Na základě výstupů Chí-kvadrát testu nelze jednoznačně tvrdit, že se jedná o uniformní skupinu zákazníků, nebot' byly zjištěny určité diference v oblasti distribučních kanálů finančních služeb (p value: $1,17926 E-05<0,05)$ a motivačních faktorů ke koupi. Při testování závislosti týkající se poptávaných produktů ( $\mathbf{p}$ value: $\mathbf{0 , 0 7 3 5 0 3 1 5 7 > 0 , 0 5 )}$ a cenové citlivosti (p value: $\mathbf{0 , 4 6 0 4 9 3 0 9 5 > 0 , 0 5}$ ) nebyly potvrzeny závislosti na př́imu. Dílčí hypotéza H4.1 a H4.2 nebyla potvrzena. Dílčí hypotéza H4.3 a H4.4 byla potvrzena.

V nejnižší př́ijmové kategorii respondentů je preferován především osobní kontakt, $\mathrm{s}$ rostoucím př́ijmem začíná mít velké opodstatnění také technologická distribuce. Na druhou stranu lidé s př́jmem nad 50000 Kč sice využívají technologickou distribuci, ale osobní kontakt stále plní zásadní roli. Tato skutečnost je dána tím, že tito zákazníci vyhledávají řešení svých finančních záležitostí prostřednictvím osobního bankéře, tzn. využívají služeb privátního bankovnictví. V oblasti distribuce finančních služeb by bylo prŕnosné zvolit diferencované distribuční strategie.

Některé motivační faktory ke koupi jsou velmi podobné v různých př́jmových kategoriích, jako je např. faktor $\mathrm{A}, \mathrm{B}, \mathrm{C}, \mathrm{G}$ (obrázek č. 2). Na druhou stranu velké diference lze sledovat u faktoru D, E, F, H. Chování zákazníků v př́ijmové kategorii 10001 - 50000 Kč je velmi podobné. Výrazné odlišnosti se týkají vymezených hraničních př́ijmových skupin. 
Obrázek 2: Motivační faktory ke koupi dle příjmu (1 - nejlepší, 5 - nejhoršíi)

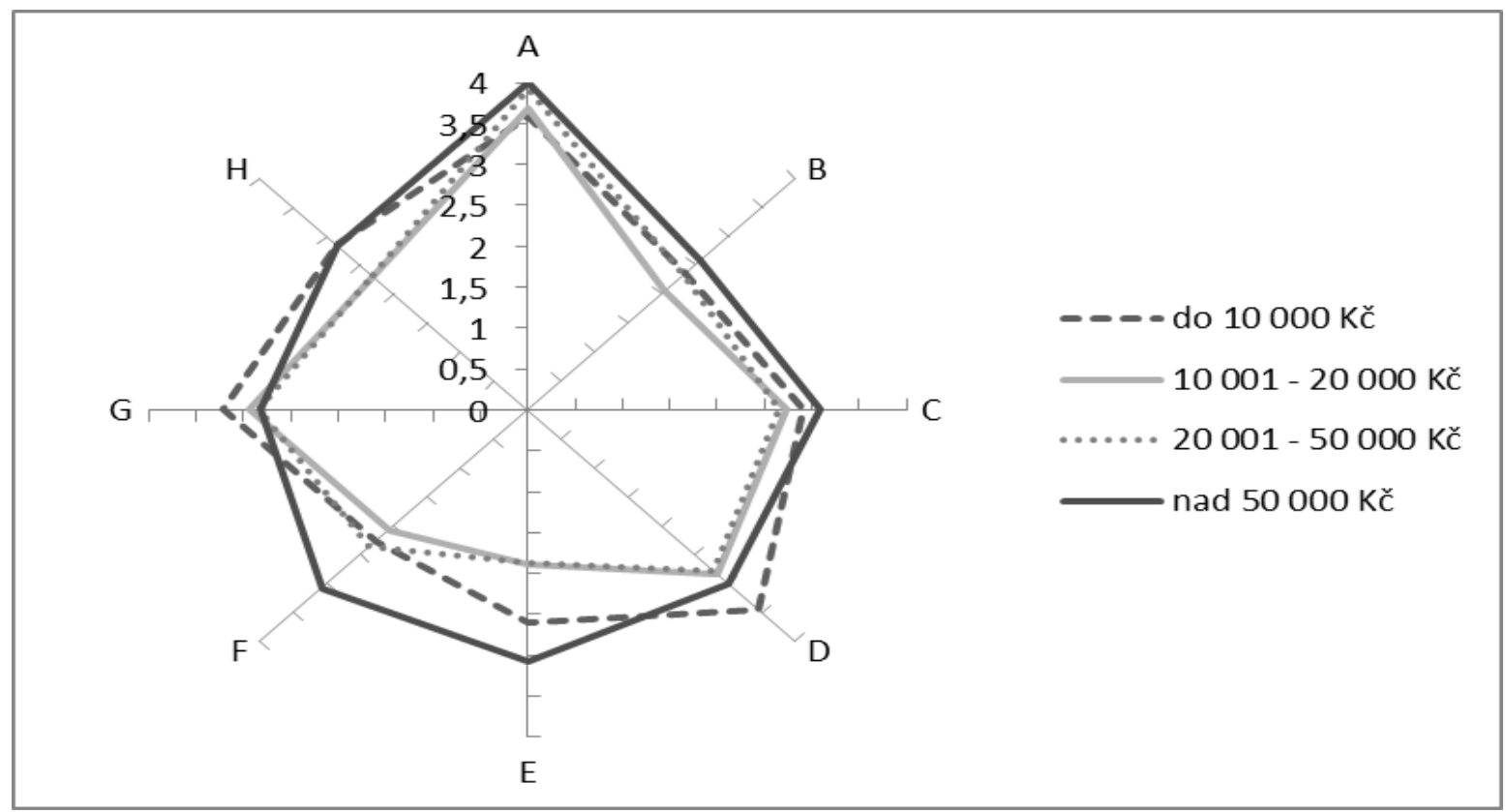

Poznámka: A: Komerční prezentace (TV, tisk, rozhlas, outdoor, Internet apod.), B:Vliv referenčních skupin, C: Veřejně dostupné reference (reportáže v médiích, diskuze na Internetu, odborné články, vyjádření odborniků), D: Doporučení od finančně poradenské firmy, E: Cenová politika, F: Dostupnost prodejních mist, G: Osobní bankér/individuální př́stup, H: Image a tradice finanční instituce

Zdroj: vlastní výzkum

\section{Závěr}

Tento článek se zaměřil na popis chování vymezené cílové skupiny zákazníků na trhu finančních služeb v České republice (Moravskoslezském kraji), a to ve věkové kategorii 50 60 let. Až do nedávné doby poskytovatelé finančních služeb měli malý zájem zacílit nabídku služeb na tuto specifickou skupinu zákazníkủ. Starší zákazníci (senioři) jsou často vnímání jako podnikatelsky neperspektivní. $\quad \mathrm{V}$ současné době však pomalu začínají české podnikatelské subjekty reagovat na skutečnost, že senioři mohou mít větší finanční zdroje než mladší věkové skupiny. Tento segment má zároveň vyšší nároky a očekávání v oblasti poskytovaných služeb než dřive. Nezanedbatelnou skutečností je také fakt, že velikost tohoto segmentu díky probíhajícím demografickým změnám se zvětšuje. V oblasti marketingu, to znamená adaptaci na nové rozvrstvení společnosti, definování nových cílových skupin, hledání vhodných způsobů, jak získat, udržet a komunikovat s touto skupinou zákazníků.

Pro potřeby tohoto článku byly analyzovány dostupné sekundární informace a také realizováno primární marketingové šetření na vybraném vzorku 306 respondentů. Na základě výstupů z primárního marketingového výzkumu byly zhodnoceny stanovené pracovní hypotézy a zjištěny skutečnosti v oblasti produktu, ceny, distribuce a marketingové komunikace. Nejfrekventovaněji využívaný finanční produkt, dle očekávání, patří běžný účet (97 \%). Zajímavé je zjištění, že pouze polovina uživatelů běžného účtu použivá v rámci platebního styku debetní platební kartu, která se k účtu váže. Krátkodobé a dlouhodobé úvěrové produkty mají spíše minoritní zastoupení. Celkově lze konstatovat, že segment 50-60 let spíše inklinuje ke spořicím produktům než k úvěrovým a sjednává si také produkty eliminující ztráty (životní a neživotní pojištění, úrazové pojištění). S cenovou politikou (poplatky, úrokové sazby, sankce apod.) finančních institucí je třetina respondentů spokojena. $55 \%$ uvádí svou nespokojenost, ale není to pro ně zásadní důvod ke změně finanční instituce. Na základě výsledků šetření lze celkově usuzovat, že česká finanční veřejnost je nespokojená, 
cenově citlivá, náročná a přesto konzervativní a pohodlná. V rámci distribuční politiky je zřejmé, že osobní kontakt je stále zcela zásadní (neoddělitelnost) mezi poskytovatelem a př́ijemcem finanční služeb. Při komunikaci s finanční institucí segment 50 - 60 let preferuje osobní kontakt, bud' na kamenné pobočce ( $42 \%$ ), na jiném domluveném místě (37\%) nebo prostřednictvím telefonu (30 \%). I když z výsledků šetření je zřejmé, že komerční komunikace je jako informační zdroj a motivační stimul pro segment 50-60 let skoro bezvýznamná. Cílová skupina není nakloněna novým marketingově komunikačním trendům, ale nabízí se zde velký komunikační potenciál v oblasti WoM (Word of Mouth nebo-li šeptandy, ústního neformálního šíření komerčního sdělení). Zároveň by mohlo být efektivní vzhledem k cílové skupině využít možnosti Event marketingu (Marketingu událostí).

Dále výstupy z realizovaného primárního marketingového výzkumu pro potřeby tohoto článku potvrzují skutečnost, že na tento segment nelze pohlížet jako na uniformní skupinu zákazníků. Je zde předpoklad heterogenních subsegmentů na základě rozdílných př́immů s rozdílnými potřebami a požadavky. Vzhledem k tomu že, senioři jako zákazníci jsou stále často ignorováni poskytovateli finančních služeb, je zde dobrá př́iležitost využít tuto tržní mezeru a implementovat do marketingových koncepcí tzv. senior-friendly marketing (seniorský přátelský marketing).

\section{Literatura}

[1] DIBB, S. and L. SIMKIN, 2004. Marketing Briefs - a Revision and Study Guide. $2^{\text {nd }}$ ed. Oxford: Elsevier. ISBN 978-0-7506-6200-0.

[2] DRUMMOND, G. and J. ENSOR, 2005. Introduction to Marketing Concepts. Oxford: Elsevier. ISBN 0-7506-59995-5.

[3] EHRLICH, E. and D. FANELLI, 2012. The financial services marketing hadnbook: tactics, techniques that produce results. $2^{\text {nd }}$ ed. New Yersey: Wiley \& Sons. ISBN 978-1118-06571-6.

[4] ENNEW, C. T., T. WATKINS and M. WRIGHT, 1995. Marketing Financial Services. Oxford: Butterworth-Heinemann, p. 45. ISBN 0-7506-2247-4.

[5] GAMBLE, P. R., N. WOODCOCK, M. STONE and B. FOSS, 2006. Up Close \& Personal?: Customer relationship marketing @ Work. $3^{\text {rd }}$ ed. London: Kogan Page. ISBN 0-7494-4691-9.

[6] JOBBER, D., 2010. Principles and Practice of Marketing. $6^{\text {th }}$ ed. Berkshire: McGrawHill Education. ISBN 978-007712330-7.

[7] KOTLER, P. and K. L. KELLER, 2012. Marketing Management. $14^{\text {th }}$ ed. Boston: Pearson Education Limited. ISBN 978-0-273-75336-0.

[8] KOZEL, R. et al., 2006. Moderní marketingový výzkum. Praha: Grada Publishing. ISBN 80-247-0966-X.

[9] LEVENS, M., 2012. Marketing: Defined, Explained, Applied. $2^{\text {nd }}$ ed. New Jersey: Pearson education. ISBN 978-0-13-271989-6.

[10] MATUŠÍNSKÁ, K., H. STARZYCZNÁ a M. STOKLASA, 2013. Pensioners and company marketing communication policy in the Czech Republic. In: Proceedings of the $4^{\text {th }}$ International Conference on Information, Communication and Education Application. Newark: Information Engineering Research Institute, s. 186-191. ISBN 978-1-6127-0569. ISSN 2160-1070. 
[11] PIRRIE, A. and P. MUDIE, 2006. Services Marketing Management. $3^{\text {rd }}$ ed. Oxford: Elsevier Ltd. ISBN 978-0-7506-6674-9.

[12] REIDL, A., 2012. Senior: zákazník budoucnosti. Brno: BizBooks. ISBN 978-80-2650018-6.

[13] WAITE, N. and C. T. ENNEW, 2007. Marketing of Financial Services. Oxford: Elsevier Ltd. ISBN 978-0-7506-6997-9.

[14] WESSLING, H., 2013. Aktivní vztah kzákaznikům pomocí CRM. Praha: Grada Publishing. ISBN 80-247-0569-9.

[15] Webový portál ČSÚ. Projekce obyvatelstva [online]. [vid. 8. srpna 2014]. Dostupné z: http://www.czso.cz/csu/2004edicniplan.nsf/p/4025-04

[16] Webový portál ČSÚ. Projekce obyvatelstva [online]. [vid. 8. srpna 2014]. Dostupné z: http://www.czso.cz/animgraf/projekce_1950_2101/index.htm

[17] Webový portál Marketingové noviny. Cílová skupina seniorů a její zvyklosti [online]. [vid. 8. srpna 2014]. Dostupné z: http://www.marketingovenoviny.cz/marketing_1941/ 